\title{
Effect of underfeeding on the inhibition of gonadotrophin secretion by testosterone propionate in rats
}

\author{
B. E. Howland \\ Department of Oral Biology, University of Manitoba, Winnipeg R3E OW3, Canada
}

\begin{abstract}
Summary. Single $(0.25 \mathrm{mg} / 100 \mathrm{~g}$ body wt) or multiple $(5 \times 20 \mu \mathrm{g} / 100 \mathrm{~g})$ injections of testosterone propionate were given to castrated male rats fed normally or restricted to a $50 \%$ intake. Serum FSH and $\mathrm{LH}$ levels were higher in the underfed rats and the effectiveness of testosterone propionate in suppressing serum levels of gonadotrophins was increased by underfeeding.
\end{abstract}

\section{Introduction}

Underfeeding in male rats results in reduced serum LH levels (Howland, 1975). The reduced stimulation of Leydig cells presumably accounts, in part, for the reduced serum levels of testosterone (Grewal, Mickelsen \& Hafs, 1971; Howland, 1975) and thus is indirectly responsible for the reduced accessory sex gland weights that are characteristic of underfed rats (Moore \& Samuels, 1931; Mulinos \& Pomerantz, 1941 a; Quimby, 1948; Berliner \& Ellis, 1965; Grewal et al., 1971; Howland, 1975). In female rats there is evidence that underfeeding causes reduced LH secretion by increasing the sensitivity of the hypothalamus or pituitary gland to the inhibitory effect of oestrogen (Howland \& Ibrahim, 1973). A similar mechanism could explain the impaired $\mathrm{LH}$ secretion in the underfed male rat.

The present study was conducted to determine the effect of underfeeding on the ability of testosterone propionate to suppress gonadotrophin secretion in castrated male rats.

\section{Materials and Methods}

Male rats of the Long-Evans strain, produced in our own colony, were used in 3 experiments. The animals were caged individually during the experimental periods and in groups at other times, in a light- $(12 \mathrm{~h}$ light $/ 12 \mathrm{~h}$ dark $)$ and temperature- $\left(23 \pm 0.5^{\circ} \mathrm{C}\right)$ controlled room. In each experiment, the rats in Group L (low food intake) were allowed to consume $50 \%$ of their normal food intake which was based on food consumption during a 3- or 4-day pre-experimental period. Animals in Group $\mathbf{N}$ (normal food intake) were not restricted in their consumption of food (Purina Laboratory Chow).

Experiment 1. The rats were castrated at 2 months of age and placed in Groups $\mathbf{L}$ or $\mathbf{N} 1$ month later. After 21 days of experimental feeding, half of the rats in each group were injected subcutaneously with testosterone propionate in sesame oil $(0.25 \mathrm{mg} / 100 \mathrm{~g}$ body wt). The other animals served as oil-treated controls. After $24 \mathrm{~h}$ each rat was lightly anaesthetized with ether and a blood sample was obtained by heart puncture. The rats were then allowed to rest for 2 months with free access to food before being reassigned, at random, to Group L or N for Exp. 2.

Experiment 2. The rats were treated as for Exp. 1 except that the dose of testosterone propionate was reduced to $0.1 \mathrm{mg} / 100 \mathrm{~g}$ body weight and the rats were decapitated (without anaesthesia) $24 \mathrm{~h}$ after the injection. Trunk blood and pituitary glands were obtained for subsequent assay for gonadotrophin concentration.

Experiment 3. The rats were castrated at 3 months of age and allocated to Group L or N 6 weeks later. Beginning on Day 16 or 17 of treatment, half of the animals in each group received a daily injection of testosterone propionate $(20 \mu \mathrm{g} / 100 \mathrm{~g}$ body wt) or the oil vehicle for 5 days. The 
hormone dose was determined on the basis of the mean body weights of the rats in each group on Days 15 and 18 of the experiment. On the day after the last injection, the rats were decapitated and trunk blood was collected. Anterior pituitary glands and ventral prostate glands were removed and weighed. Pituitary glands and serum were stored frozen until assayed for gonadotrophin concentration.

Assays. The concentrations of LH and FSH in pituitary homogenates and sera were determined by double-antibody radioimmunoassays (see Howland, 1975). The method of Niswender, Midgley, Monroe \& Reichert (1968) was used for LH; FSH was determined by the assay distributed by the National Institute of Arthritis, Metabolism and Digestive Diseases, NIH. Values for $\mathrm{LH}$ and FSH, based on duplicate determinations, are reported in terms of NIAMDD-rat-LH-RP1 and NIAMDD-rat-FSH-RP1, respectively. The sensitivities of the assays were $5 \mathrm{ng} \mathrm{LH} / \mathrm{ml}$ and $100 \mathrm{ng} \mathrm{FSH} / \mathrm{ml}$ for $90 \%$ binding and the inter-assay coefficients of variation were $12.7 \%$ for $\mathrm{LH}$ and $\mathbf{1 0} \cdot 4 \%$ for $\mathrm{FSH}$.

The data were assessed by analysis of variance (Steele \& Torrie, 1960).

\section{Results}

The results of Exps 1 and 2 are summarized in Table 1. Body weight of the Group $L$ rats was reduced $(P<0.01)$ in both experiments. Serum levels of LH were about twice as high in the control animals in Group $\mathrm{L}$ than in those in Group $\mathrm{N}$ but were suppressed to similar low levels in both groups by hormone treatment. (food intake $\times$ hormone treatment, $P<0.01$, in both experiments). The elevation of serum FSH levels was significant $(P<0.01)$ only in Exp. 2 . There were no treatment effects on pituitary weight or LH concentration, but pituitary FSH concentration was elevated $(P<0.05)$ in the rats treated with testosterone propionate.

In Exp. 3 (Table 2) body and pituitary weights were lower in Group L than in Group $N$ rats $(P<0.01)$. Pituitary weight was also suppressed $(P<0.05)$ by testosterone treatment. The increase in weight of the ventral prostate in the hormone-treated rats $(P<0.01)$ was greater in Group $\mathrm{L}$ than in Group $\mathrm{N}$ (food intake $\times$ hormone treatment, $P<0.05$ ). Pituitary concen-

Table 1. Effect of a single injection of testosterone propionate on pituitary weight and serum and pituitary gonadotrophin levels in castrated male rats fed normally (Group N) or restricted to a $50 \%$ intake (Group L)

\begin{tabular}{|c|c|c|c|c|}
\hline & \multicolumn{2}{|c|}{ Group N } & \multicolumn{2}{|c|}{ Group L } \\
\hline & $\begin{array}{c}\text { Oil } \\
\text { (control) }\end{array}$ & $\begin{array}{c}\text { Testosterone } \\
\text { propionate }\end{array}$ & $\begin{array}{c}\text { Oil } \\
\text { (control) }\end{array}$ & $\begin{array}{c}\text { Testosterone } \\
\text { propionate }\end{array}$ \\
\hline \multicolumn{5}{|l|}{ Experiment $1^{*}$} \\
\hline Body wt (g) & $378 \pm 9$ & $367 \pm 1$ & $256 \pm 6$ & $254 \pm 4$ \\
\hline Serum LH (ng/ml) & $644 \pm 33$ & $101 \pm 17$ & $1247 \pm 131$ & $88 \pm 10$ \\
\hline Serum FSH $(\mathrm{ng} / \mathrm{ml})$ & $2463 \pm 106$ & $2620 \pm 332$ & $2712 \pm 141$ & $3256 \pm 336$ \\
\hline \multicolumn{5}{|l|}{ Experiment $2 \dagger$} \\
\hline Body wt $(\mathrm{g})$ & $462 \pm 9$ & $424 \pm 15$ & $330 \pm 8$ & $333 \pm 8$ \\
\hline \multicolumn{5}{|l|}{ Pituitary } \\
\hline Weight (mg) & $15 \cdot 3 \pm 0.6$ & $13 \cdot 3 \pm 1 \cdot 4$ & $14.0 \pm 0.6$ & $14.5 \pm 0.7$ \\
\hline $\mathrm{LH}$ conc. $(\mu \mathrm{g} / \mathrm{mg})$ & $103 \pm 8$ & $101 \pm 8$ & $110 \pm 6$ & $107 \pm 6$ \\
\hline FSH conc. $(\mu \mathrm{g} / \mathrm{mg})$ & $18.6 \pm 1.2$ & $20.8 \pm 1.4$ & $19.1 \pm 0.8$ & $22 \cdot 6 \pm 1 \cdot 0$ \\
\hline \multicolumn{5}{|l|}{ Serum } \\
\hline LH conc. $(\mathrm{ng} / \mathrm{ml})$ & $419 \pm 20$ & $166 \pm 25$ & $893 \pm 87$ & $202 \pm 63$ \\
\hline FSH conc. $(\mathrm{ng} / \mathrm{ml})$ & $2190 \pm 131$ & $2190 \pm 189$ & $2858 \pm 124$ & $3044 \pm 94$ \\
\hline
\end{tabular}

* Values are mean \pm s.e.m., 11 or 12 rats/group treated with $0.25 \mathrm{mg} / 100 \mathrm{~g}$ body wt.

$\dagger$ Values are mean \pm s.e.m., $10-12$ rats/group treated with $0.1 \mathrm{mg} / 100 \mathrm{~g}$ body wt. 
Table 2. Effect of 5 daily injections of testosterone propionate $(20 \mu \mathrm{g} / 100 \mathrm{~g}$ body wt) on organ weights and serum and pituitary levels of gonadotrophins in castrated male rats fed normally

(Group N) or restricted to a $50 \%$ intake (Group L)

\begin{tabular}{|c|c|c|c|c|}
\hline & \multicolumn{2}{|c|}{ Group N } & \multicolumn{2}{|c|}{ Group L } \\
\hline & $\begin{array}{c}\text { Oil } \\
\text { (control) }\end{array}$ & $\begin{array}{l}\text { Testosterone } \\
\text { propionate }\end{array}$ & $\begin{array}{c}\text { Oil } \\
\text { (control) }\end{array}$ & $\begin{array}{c}\text { Testosterone } \\
\text { propionate }\end{array}$ \\
\hline Body wt $(\mathrm{g})$ & $460 \pm 8$ & $455 \pm 5$ & $373 \pm 6$ & $381 \pm 4$ \\
\hline $\begin{array}{l}\text { Ventral prostate wt }(\mathrm{mg}) \\
\text { Pituitary }\end{array}$ & $32 \cdot 9 \pm 2 \cdot 0$ & $71 \cdot 3 \pm 1 \cdot 7$ & $28 \cdot 7 \pm 1 \cdot 1$ & $76 \cdot 6 \pm 2 \cdot 3$ \\
\hline Weight (mg) & $14.7 \pm 0.6$ & $13.9 \pm 0.4$ & $13 \cdot 2 \pm 0 \cdot 6$ & $11.9 \pm 0.4$ \\
\hline LH conc. $(\mu \mathrm{g} / \mathrm{mg})$ & $116 \pm 7$ & $133 \pm 6$ & $153 \pm 9$ & $190 \pm 10$ \\
\hline FSH conc. $(\mu \mathrm{g} / \mathrm{mg})$ & $19 \cdot 2 \pm 1 \cdot 4$ & $27 \cdot 1 \pm 2 \cdot 3$ & $22 \cdot 6 \pm 1 \cdot 2$ & $34 \cdot 3 \pm 2 \cdot 0$ \\
\hline Serum & & & & \\
\hline LH conc. $(\mathrm{ng} / \mathrm{ml})$ & $493 \pm 33$ & $277 \pm 63$ & $1064 \pm 77$ & $42 \pm 7$ \\
\hline FSH conc. $(\mathrm{ng} / \mathrm{ml})$ & $2350 \pm 114$ & $2295 \pm 127$ & $3227 \pm 106$ & $2497 \pm 140$ \\
\hline
\end{tabular}

Values are mean \pm s.e.m., 13 or 14 rats/group.

trations of LH and FSH were elevated $(P<0.01)$ by hormone treatment and by low food intake. Serum concentrations of LH and FSH were elevated in Group L rats $(P<0.01)$ and reduced by testosterone treatment $(P<0.01)$, the reduction being greater in Group $\mathrm{L}$ rats than that in rats in Group $\mathrm{N}$ (food intake $\times$ hormone treatment, $P<0.01$ ).

\section{Discussion}

The high serum levels of gonadotrophins noted in the control rats in Group $L$ in the present experiment indicate that the pituitary can secrete adequate amounts of gonadotrophins under conditions of severe food restriction provided the inhibitory influence of gonadal hormones is absent. The reason for the higher LH concentrations in Group L rats is not readily explained. Changes in metabolic clearance rate, serum volume and secretion rate could have occurred. The fact that the high gonadotrophin levels were effectively reduced by testosterone propionate treatment suggests that a high rate of secretion was largely responsible for the difference.

The use of a single injection of testosterone propionate yielded equivocal results. Rats in Group $\mathrm{L}$ were more sensitive to the inhibitory effect of androgen as measured by the magnitude of the change in $\mathrm{LH}$, but the final concentrations in the two groups were similar. When daily injections of testosterone propionate were used (Exp. 3) the LH levels in Group L rats dropped to levels that were considerably below those in Group $\mathbf{N}$ rats. These data suggest that the hypothalamic-pituitary complex of the underfed male rat is more sensitive to the inhibitory effects of androgen than is that of the adequately fed animal, and are consistent with the reported increase in the inhibitory effect of oestrogen in underfed female rats (Howland \& Ibrahim, 1973). This interpretation does not preclude the possibility that nutritionally induced alterations in the rate of absorption or metabolism of injected steroid could have contributed to the results. It is possible that the apparent changes in sensitivity of the hypothalamic-pituitary complex to gonadal steroids after relatively short periods of underfeeding may not persist during longer periods of restricted food intake. Walker \& Frawley (1977) have reported that female rats underfed since birth did not show this increased sensitivity to oestrogen.

The results of the present experiments indicate that serum FSH concentrations were elevated by underfeeding. This was particularly evident in Exp. 3. The elevation in the serum levels of both gonadotrophins in Exp. 3 was associated with elevations in pituitary concentration of these hormones, suggesting that the rate of synthesis was more than adequate to keep pace with the rate of hormone release. Serum FSH levels were not affected by a single injection of androgen but pituitary FSH concentrations were increased, and were more obviously so after several 
injections. The elevation of pituitary FSH and the reduction or no change in serum FSH following testosterone propionate treatment is generally consistent with data reported for castrated (Gay \& Bogdanove, 1969; Kamberi \& McCann, 1972) or intact rats (Chowdhury \& Steinberger, 1976). The suppression of serum FSH in the underfed rats provides further evidence of a nutritionally induced altered sensitivity to androgens.

The elevated concentrations of pituitary LH found after testosterone propionate treatment in the present study are at variance with reports by Gay \& Bogdanove (1969) for castrated rats and Chowdhury \& Steinberger (1976) for intact male rats. The pituitary and serum gonadotrophin data clearly show that elevations in pituitary concentration of gonadotrophins can be associated with either elevated (underfeeding) or depressed serum levels of gonadotrophins depending on the treatment imposed.

Although not a primary objective of this study, the responsiveness of ventral prostate to androgen was measured in Exp. 3. The observation that the animals in Group L responded well to exogenous androgen is in agreement with earlier studies by Mulinos \& Pomerantz (1941b) and Quimby (1948). The underfed rats responded better to an identical dose of androgen/unit body weight. Whether this difference represents a true difference in accessory sex gland responsiveness or is partly a reflection of a treatment effect on the metabolic clearance rate of androgens is presently unknown. However, it is clear that the reduced accessory sex gland weights that have been observed in underfed male rats must be attributed to reduced androgen secretion rather than any defect in ability to respond to androgen.

This work was supported, in part, by grant MA 4454 from the Medical Research Council of Canada. I thank Dr G. D. Niswender, Dr L. E. Reichert, Jr and the NIAMDD for supplying radioimmunoassay materials, and $\mathrm{Mr} \mathrm{D}$. B. Beaton for excellent technical assistance.

\section{References}

Berliner, D. \& Ellis, L.C. (1965) The effects of irradiation on endocrine cells. I. A comparison between the effects of inanition and irradiation on androgen production by murine testicular tissue. Radiat. Res. 24, 572-578.

Chowdhury, M. \& Steinberger, E. (1976) Differences of the effects of testosterone propionate on the production of LH and FSH. Acta endocr., Copenh. 82, 683-690.

Gay, V.L. \& Bogdanove, E.M. (1969) Plasma and pituitary $\mathrm{LH}$ and $\mathrm{FSH}$ in the castrated rat following short-term steroid treatment. Endocrinology 84, 1132-1142.

Grewal, T., Mickelsen, D. \& Hafs, H.D. (1971) Androgen secretion and spermatogenesis in rats following semistarvation. Proc. Soc. exp. Biol. Med. 138, $723-727$.

Howland, B.E. (1975) The influence of feed restriction and subsequent refeeding on gonadotrophin secretion and serum testosterone levels in male rats. $J$. Reprod. Fert. 44, 429-436.

Howland, B.E. \& Ibrahim, E.A. (1973) Increased LHsuppressing effect of oestrogen in ovariectomized rats as a result of underfeeding. $J$. Reprod. Fert. 35, 545-548.

Kamberi, I.A. \& McCann, S.M. (1972) Effects of implants of testosterone in the median eminence and pituitary on FSH secretion. Neuroendocrinology 9, 20-29.

Moore, C.R. \& Samuels, L.T. (1931) The action of testes hormone in correcting changes induced in rat prostate or seminal vesicles by vitamin B or partial inanition. Am. J. Physiol. 96, 278-288.

Mulinos, M.G. \& Pomerantz, L. (1941a) The reproductive organs in malnutrition. Effects of chorionic gonadotrophin upon atrophic genitalia of underfed male rats. Endocrinology 29, 267-275.

Mulinos, M.G. \& Pomerantz, L. (1941b) Hormonal influences on the weight of the adrenal in inanition. Am. J. Physiol. 132, 368-374.

Niswender, G.D., Midgley, A.R. Jr., Monroe, S.E. \& Reichert, L.E. Jr. (1968) Radioimmunoassay for rat luteinizing hormone with anti-ovine $\mathrm{LH}$ serum and ovine- ${ }^{131}$ I. Proc. Soc. exp. Biol. Med. 128, 807-811.

Quimby, F.H. (1948) Organ weights of rats receiving hormone supplements during recovery from chronic starvation. Endocrinology 42, 263-272.

Steele, R.G.D. \& Torrie, J.H. (1960) Principles and Procedures of Statistics. McGraw-Hill Book Company, Inc., New York.

Walker, R.F. \& Frawley, L.S. (1977) Gonadal function in underfed rats. II. Effect of estrogen on plasma gonadotropins after pinealectomy or constant light exposure. Biol. Reprod. 17, 630-634. 